\title{
PENYEBAB LANGSUNG DAN PENYEBAB TIDAK LANGSUNG TERJADINYA STUNTING PADA ANAK BALITA
}

\author{
Legina Anggraeni*, Mella Yuria, Maryuni, Irwanti Gustina \\ Fakultas Keperawatan dan Kebidanan (D III Kebidanan), Universitas Binawan, Jakarta, Indonesia \\ email: legina@binawan.ac.id
}

\begin{abstract}
Abstrak
Stunting merupakan masalah gizi anak yang mengkhawatirkan. Dampak yang ditimbulkan dari kondisi tersebut antara lain dapat menghambat pertumbuhan dan perkembangan otak sehingga berisiko mengalami penurunan kemampuan intelektual dan berisiko mengalami penyakit degeneratif dikemudian hari. Ada dua klasifikasi penyebab dari stunting yaitu penyebab langsung dan penyebab tidak langsung. Tujuan penelitian ini adalah ingin mengetahui hubungan antara penyebab langsung dan penyebab tidak langsung kejadian stunting. Metode yang digunakan adalah kuantitatif dengan desain cross sectional di wilayah Kecamatan Kramat Jati, Jakarta Timur. Sampel yang digunakan sebesar 75 responden. Teknik pengumpulan data menggunakan kuesioner dan dilakukan pengukuran berat badan serta tinggi badan secara langsung kepada balita. Hasil yang diperoleh pada penelitian ini terdapat hubungan yang signifikan antara penyebab langsung (berat badan lahir dengan p-value 0,001 dan tinggi badan ibu dengan p-value 0,022) dan penyebab tidak langsung (pola asuh dengan $p$ value 0,002, pendidikan ibu dengan p-value 0,03, pengetahuan dengan p-value 0,043) terhadap kejadian stunting pada balita. Kesimpulan dari penelitian ini adalah terdapat hubungan antara berat lahir, tinggi badan ibu, pola asuh, pendidikan ibu dan pengetahuan terhadap kejadian stunting. Saran kepada tenaga kesehatan untuk memberikan edukasi pra nikah dan memperkuat pelayanan kepada ibu hamil untuk mencegah komplikasi yang dapat menimbulkan stunting pada anak yang dilahirkan.
\end{abstract}

Kata kunci : Stunting, balita, penyebab langsung, penyebab tidak langsung

\begin{abstract}
Stunting is a worrying child nutrition problem. The impact of these conditions, among others, can inhibit brain growth and development so that they are at risk of decreased intellectual ability and at risk developing degenerative diseases in the future. There are two classifications of stunting events: direct causes and indirect causes. This study aimed to find out the relationship between immediate causes and indirect causes with stunting events. The method used is quantitative with a cross-sectional design in Kramat Jati subdistrict, East Jakarta 75 respondents used the sample. Data collection techniques using questionnaires and measurements of weight and height directly to toddlers. The results obtained in this study there is a significant relationship between direct causes (birth weight with a p-value of 0.001 and length of mother's body with a p-value of 0.022) and indirect causes (parenting with a p-value of 0.002, maternal education with a p-value of 0.03, knowledge with a p-value of 0.043) to stunting events in toddlers. This study a concludes a relationship between weight birth, maternal height, parenting, maternal education and knowledge to stunting events. Advice health workers to provide premarital education and strengthen services to pregnant women to prevent complications that can cause stunting in children born.
\end{abstract}

Keywords : Stunting, toddler, direct cause, indirect cause

\section{PENDAHULUAN}

Menurut Badan Kesehatan Dunia World Health Organization (WHO) stunting atau yang biasa dikenal dengan sebutan kerdil atau pendek merupakan suatu kondisi dimana anak memiliki panjang badan atau tinggi badan yang kurang jika dibandingkan dengan usianya. Kejadian stunting atau pendek merupakan salah satu masalah gizi yang dialami oleh sebagian besar anak usia 
balita di dunia saat ini terutama pada anak di Negara berkembang (Kemenkes RI, 2018). Anak yang menderita stunting dapat dipastikan akan mengalami pertumbuhan dan perkembangan yang terhambat dibandingkan dengan anak-anak normal seusianya (World Health Organization, 2016).

Masalah stunting pada balita perlu mendapat perhatian khusus karena dapat menghambat pertumbuhan fisik dan perkembangan mental anak. Balita yang mengalami stunting memiliki peluang lebih besar untuk mengalami penurunan kemampuan kecerdasan, produktivitas dan peningkatan risiko penyakit degenerative ketika dewasa (Ramlah, 2014) .

Pada tahun 2017 diperkirakan sekitar 150,8 juta balita di seluruh dunia mengidap stunting dan lebih dari setengah balita stunting di dunia berasal dari kawasan Asia sebesar yaitu sebesar 55\% sedangkan, lebih dari sepertiganya yaitu sebesar 39\% tinggal di Benua Afrika. Sebesar 83,6 juta balita stunting berada di kawasan Asia dan proporsi tertinggi berasal dari Asia Selatan (58,7\%) serta proporsi paling rendah terjadi di Asia Tengah (0,9\%) (Kemenkes RI, 2018).

Global Nutrition Report Tahun 2014 menunjukkan bahwa Negara Indonesia berada pada urutan 17 di antara 117 negara, yang mempunyai tiga masalah gizi yaitu stunting, wasting dan overweight pada balita. Menurut data yang dihimpun oleh Badan Kesehatan Dunia, Indonesia menempati posisi ketiga dengan angka stunting tertinggi di wilayah Asia Tenggara/South-East Asia Regional (SEAR) (International Food Policy Research Institute, 2014). Pada tahun 2017 prevalensi kejadian stunting di Provinsi DKI Jakarta sebesar $22,7 \%$ dengan kasus tertinggi terdapat di Jakarta Pusat $(29,2 \%)$ dan tertinggi kedua berada di Kota Administratif Jakarta Timur (25,7\%) (Dinas Kesehatan DKI Jakarta, 2017).

Stunting disebabkan oleh faktor multi dimensi. Penelitian yang dilakukan pada tahun 2016 mengemukakan bahwa kejadian stunting akan bergantung pada sanitasi lingkungan tempat tinggal, kebersihan air, dan ketersediaan. Perilaku hidup bersih dan sehat serta keterbatasan fasilitas kebersihan dapat berdampak pada status gizi anak, dimana dapat menyebabkan berbagai penyakit infeksi (Torlesse, et al, 2016).

Terdapat faktor risiko lain seperti jenis kelamin dimana laki-laki memiliki peluang lebih besar mengalami stunting, pendapatan keluarga yang rendah, fasilitas kesehatan tertutama pelayanan antenatal care yang belum memadai, dan pendidikan ibu serta pengetahuan yang minim terhadap asupan nutrisi yang baik untuk anak dibawah lima tahun mempengaruhi angka kejadian stunting pada anak (Fitri, 2012).

Gaya parenting (pola asuh) yang diterapkan oleh orang tua juga sangat mempengaruhi terhadap tingginya kejadian stunting yang dialami oleh anak balita. Pola asuh orang tua yang kurang atau rendah memiliki peluang lebih besar anak terkena stunting dibandingkan orang tua dengan pola asuh baik (Aramico, 2013). Diantara banyaknya faktor pencetus terjadinya stunting pada balita, pola makan yang buruk, pendapatan yang rendah, tinggi badan ibu yang pendek, berat badan ibu yang kurang dan tingkat pendidikan ibu yang rendah adalah lima faktor yang memiliki kontribusi paling besar terhadap kejadian stunting pada anak balita.

Tujuan penelitian ini adalah untuk mengetahui penyebab langsung dan penyebab tidak langsung terhadap kejadian stunting pada balita.

\section{METODE PENELITIAN}

Penelitian ini merupakan penelitian kuantitatif dengan menggunakan desain penelitian cross sectional. Responden penelitian ini merupakan ibu yang memiliki balita yang sudah disesuaikan berdasarkan kriteria inkulusi dan eksklusi yaitu sebesar 75 responden. Tempat penelitian dilakukan di wilayah kerja Kecamatan Kramat Jati Jakarta Timur.

Teknik pengambilan data pada penelitian ini menggunakan data primer melalui pengisian kuesioner yang diisikan langsung oleh para responden penelitian. Selain itu peneliti juga mengukur berat badan balita menggunakan timbangan digital dan melakukan pengukuran tinggi badan balita menggunakan pita ukur. 
Analisa yang digunakan adalah analisa univariat untuk mengetahui distribusi frekuensi variabel-variabel penelitian seperti kejadian stunting, karakteristik ibu (tingkat pendidikan, pengetahuan ibu, dan tinggi badan ibu), pola asuh ibu dan berat badan lahir. Selanjutnya variabel tersebut akan dianalisa lebih lanjut menggunakan analisa bivariat uji chi square. Hal tersebut memiliki tujuan untuk mengetahui hubungan antara variabel independen (penyebab langsung) seperti berat badan lahir dan tinggi ibu, (penyebab tidak langsung) seperti pola asuh, pendidikan ibu dan pengetahuan ibu dengan variabel dependen (kejadian stunting).

\section{HASIL DAN PEMBAHASAN}

Berikut disajikan data tentang kejadian stunting, penyebab langsung dan penyebab tidak langsung kejadian stunting pada anak balita seperti yang disajikan pada tabel 1 .

Tabel 1. Distribusi Frekuensi Kejadian Stunting, Penyebab Langsung dan Penyebab Tidak Langsung Kejadian Stunting pada Anak Balita

\begin{tabular}{lcc}
\hline Variabel & Frekuensi (n) & Persentase (\%) \\
\hline Kejadian Stunting & 22 & \\
$\quad$ Stunting & 53 & 29,3 \\
$\quad$ Tidak Stunting & & 70,7 \\
Berat Badan Lahir & 57 & \\
$\quad \geq 2500$ gram & 18 & 76,0 \\
$\quad$ < 2500 gram & & 24,0 \\
Pola Asuh & 58 & 77,3 \\
$\quad$ Baik & 17 & 22,7 \\
$\quad$ Kurang baik & & \\
Pendidikan Ibu & 54 & 72,0 \\
$\quad$ Tinggi & 21 & 28,0 \\
$\quad$ Rendah & & \\
Pengetahuan Ibu & 34 & 45,3 \\
$\quad$ Baik & 41 & 54,7 \\
$\quad$ Kurang baik & & \\
Tinggi Badan Ibu & 60 & 80,0 \\
$\quad \geq 150 \mathrm{~cm}$ & 15 & 20,0 \\
$\quad<150 \mathrm{~cm}$ & & \\
\hline
\end{tabular}

Hasil analisa univariat yang dapat dilihat pada tabel 1 menunjukan bahwa sebesar 29,3\% (22 balita) mengalami stunting, sedangkan sisanya sebesar $70,7 \%$ (53 balita) tidak mengalami stunting. Berat badan lahir didominasi dengan berat badan lahir normal (2.500 - 4.000 gram) sebesar $76 \%$ dan sisanya sebesar $24 \%$ masuk kedalam kategori berat badan lahir tidak normal (< 2500 gram). Sedangkan, untuk variabel pola asuh yang diterapkan oleh orang tua didapatkan hasil bahwa sebanyak 58 orang tua menerapkan pola asuh yang baik dan sisanya sebanyak 17 orang menerapkan pola asuh yang kurang baik. pendidikan ibu didominasi dengan pendidikan tinggi (SMA/SederajatPerguruan Tinggi) sebesar 54\% dan sisanya sebanyak $21 \%$ memiliki pendidikan yang rendah (SD dan SMP/Sederajat). Sebesar $54,7 \%$ ibu memiliki pengetahuan yang kurang baik tentang stunting dan sisanya sebesar $45,3 \%$ memiliki pengetahuan yang baik. Tinggi badan ibu didominasi dengan tinggi badan $\geq 150 \mathrm{~cm}$ sebesar $80 \%$ dan tinggi badan $<150 \mathrm{~cm}$ sebesar $20 \%$. 
Tabel 2. Hubungan Antara Penyebab Langsung dan Penyebab Tidak Langsung Terhadap Kejadian Stunting Pada Anak Balita

\begin{tabular}{|c|c|c|c|c|c|c|c|c|}
\hline \multirow{3}{*}{ Variabel } & \multicolumn{4}{|c|}{ Stunting } & \multirow{2}{*}{\multicolumn{2}{|c|}{ TOTAL }} & \multirow{3}{*}{ P-Value } & \multirow{3}{*}{ OR } \\
\hline & \multicolumn{2}{|c|}{ Tidak Stunting } & \multicolumn{2}{|c|}{ Stunting } & & & & \\
\hline & $\mathbf{N}$ & $\%$ & $\mathbf{N}$ & $\%$ & $\mathbf{N}$ & $\%$ & & \\
\hline \multicolumn{9}{|c|}{ Penyebab Langsung } \\
\hline \multicolumn{9}{|c|}{ Berat Badan Lahir } \\
\hline$\geq 2500$ gram & 46 & 61,3 & 11 & 14,7 & 57 & 76 & \multirow{3}{*}{0,001} & \multirow{3}{*}{6,571} \\
\hline$<2500$ gram & 7 & 9,3 & 11 & 14,7 & 18 & 24 & & \\
\hline Total & 53 & 70,6 & 22 & 29,4 & 75 & 100 & & \\
\hline \multicolumn{9}{|c|}{ Tinggi Badan Ibu } \\
\hline$\geq 150 \mathrm{~cm}$ & 46 & 61,3 & 14 & 18,7 & 60 & 80 & \multirow{3}{*}{0,022} & \multirow{3}{*}{3,775} \\
\hline$<150 \mathrm{~cm}$ & 7 & 9,4 & 8 & 10,6 & 15 & 20 & & \\
\hline Total & 53 & 70,7 & 22 & 29,3 & 75 & 100 & & \\
\hline \multicolumn{9}{|c|}{ Penyebab Tidak Langsung } \\
\hline \multicolumn{9}{|l|}{ Pola Asuh } \\
\hline Baik & 46 & 61,3 & 12 & 16 & 58 & 77,3 & \multirow{3}{*}{0,002} & \multirow{3}{*}{5,476} \\
\hline Kurang Baik & 7 & 9,4 & 10 & 13,3 & 17 & 22,7 & & \\
\hline Total & 53 & 70,7 & 22 & 29,3 & 75 & 100 & & \\
\hline \multicolumn{9}{|c|}{ Pengetahuan Ibu } \\
\hline Baik & 28 & 37,3 & 6 & 8 & 34 & 45,3 & \multirow{3}{*}{0,043} & \multirow{3}{*}{2,987} \\
\hline Kurang Baik & 25 & 33,4 & 16 & 21,3 & 41 & 54,7 & & \\
\hline Total & 53 & 70,7 & 22 & 29,3 & 75 & 100 & & \\
\hline \multicolumn{9}{|l|}{ Pendidikan Ibu } \\
\hline Tinggi & 42 & 56 & 12 & 16 & 54 & 72 & \multirow{3}{*}{0,03} & \multirow{3}{*}{3,182} \\
\hline Rendah & 11 & 14,7 & 10 & 13,3 & 21 & 28 & & \\
\hline Total & 53 & 70,7 & 22 & 29,3 & 75 & 100 & & \\
\hline
\end{tabular}

\section{Hubungan Penyebab Langsung dengan Kejadian Stunting}

Berdasarkan hasil uji bivariat pada tabel 2 ditemukan hasil bahwa terdapat hubungan yang signifikan antara berat badan lahir dengan kejadian stunting dengan p-value 0,001 . Bayi dengan berat badan lahir rendah memiliki resiko untuk mengalami stunting sebesar 6,571 kali lebih besar dari pada bayi dengan berat badan lahir normal $(\mathrm{OR}=$ $6,571)$.

Hal ini sejalan dengan penelitian yang dilakukan oleh Nurjanah (2018) yang menyatakan bahwa bayi dengan berat badan lahir rendah (BBLR) berhubungan secara signifikan dengan kejadian stunting dengan p-value sebesar 0,0001. Penelitian lainnya yang dilakukan oleh (Sulistiyawati, 2019) menyatakan bahwa bayi dengan Riwayat BBLR memiliki risiko untuk menjadi stunting sebesar 4,625 kali lebih besar dibandingkan dengan bayi yang tidak memiliki riwayat BBLR.

BBLR merupakan suatu kondisi dimana seorang bayi dilahirkan dengan berat badan kurang dari 2.500 gram tanpa memandang usia kandungan. Berat badan lahir dapat menjadi salah satu indikator dalam menilai kelangsungan hidup, pertumbuhan, kesehatan jangka panjang, dan perkembangan psikologis anak. Penilaian antropometri pada bayi baru lahir merupakan metode yang digunakan untuk mengkaji prognosis bayi baru lahir. Bayi dengan berat badan rendah memiliki pengaruh pada angka morbiditas dan mortalitas (Irawati, 2014).

$$
\text { Menurut Proverawati (2010) }
$$
menyatakan bahwa, bayi yang terlahir dengan BBLR tipe kecil masa kehamilan (dismatur), sejak dalam kandungan telah mengalami retardasi pertumbuhan dan dikemudian hari akan berpengaruh dalam proses pertumbuhan dan perkembangan. Bayi dengan kondisi tersebut akan mengalami pertumbuhan dan perkembangan yang lebih lambat dari bayi yang dilahirkan dengan berat badan normal, serta pola pertumbuhannya akan berada dibawah tingkat pertumbuhan yang seharusnya dicapai pada anak seusianya. 
Hasil analisa lainnya menyebutkan bahwa terdapat hubungan yang signifikan antara tinggi badan ibu dengan kejadian stunting pada balita dengan p-value sebesar 0,022 . Balita yang lahir dari ibu yang memiliki tinggi badan $<150 \mathrm{~cm}$ berpotensi 3,755 kali lebih besar menderita stunting dibandingkan dengan balita yang lahir dari ibu yang memililiki tinggi badan $\geq 150 \mathrm{~cm}$.

Penelitian lain yang mendukung hasil penelitian ini adalah penelitian yang dilakukan oleh Ibrahim et al., 2019 yang menyatakan bahwa terdapat hubungan bermakna antara tinggi badan ibu dengan kejadian stunting dengan $\mathrm{p}$-value sebesar 0.011 .

Tinggi badan ibu sangat berkaitan dengan cadangan makanan baik. Cadangan makanan yang baik dalam rentang waktu yang panjang maupun pendek akan berpengaruh kepada komponen tubuh. Ibu yang memiliki postur tubuh tinggi dan bergizi baik memiliki riwayat baik dalam menyediakan cadangan energi kepada janin dibandingkan dengan ibu yang pendek dengan status gizi kurang (Wells, 2013).

Tinggi badan merupakan komponen yang fundamental sebagai indikator status gizi, dengan menghubungkan berat badan terhadap tinggi badan. Sehingga pengukuran tinggi badan seseorang secara akurat sangatlah penting untuk menentukan nilai Indeks Massa Tubuh (IMT) dan merupakan faktor yang diturunkan kepada anak serta berkaitan dengan kejadian stunting (Yabanc, 2014)

\section{Hubungan Penyebab Tidak Langsung dengan Kejadian Stunting}

Berdasarkan hasil uji bivariat yang tersaji didalam tabel 2 ditemukan bahwa terdapat hubungan yang signifikan antara pola asuh yang diberikan oleh orang tua dengan kejadian stunting pada anak balita dengan p-value 0,002. Anak yang diasuh dengan pola asuh kurang baik memiliki risiko 5,476 kali lebih besar menderita stunting dibandingkan dengan anak yang diasuh dengan pola asuh baik.

Penelitian ini sejalan dengan penelitian yang dilakukan oleh $\mathrm{Ra}$ (2021) yang menyatakan bahwa terdapat hubungan yang signifikan antara pola asuh dengan kejadian stunting dengan nilai $\mathrm{p}$ yaitu 0,0001 . Pola asuh disini diartikan sebagai perilaku orang tua yang berkaitan dengan perilaku kesehatan. Pola asuh orang tua merupakan salah satu masalah yang dapat mempengaruhi terjadinya stunting pada balita. Pola asuh orang tua yang kurang atau rendah memiliki peluang lebih besar anak terkena stunting dibandingkan orang tua dengan pola asuh baik (Aramico, 2013).

Pola asuh terhadap anak dimanifestasikan dalam beberapa hal berupa pemberian ASI dan makanan pendamping, rangsangan psikososial, perawatan anak dalam keadaan sakit dan pola pencarian pelayanan kesehatan. Kebiasaan yang ada di dalam keluarga berupa praktik pemberian makan, rangsangan psikososial, praktik kebersihan/hygiene, sanitasi lingkungan dan pemanfaatan pelayanan kesehatan mempunyai hubungan yang signifikan dengan kejadian stunting anak usia $24-59$ bulan (Rahmayana, 2014).

Berdasarkan hasil analisa bivariat lainnya menyebutkan bahwa terdapat hubungan yang signifikan antara pendidikan ibu dengan kejadian stunting dengan p-value sebesar 0,03 . Ibu dengan pendidikan rendah memiliki peluang 3,182 kali lebih besar melahirkan anak dengan kondisi stunting dibandingkan dengan ibu dengan pendidikan tinggi.

Tingkat pendidikan terutama tingkat pendidikan ibu memiliki pengaruh terhadap kesehatan keluarganya, salah satunya adalah status gizi dari anggota keluarga. Pendidikan ibu juga mempengaruhi pola asuh pada anak, karena ibu sebagai pembina pertama dan utama terhadap kesehatan anak, pengelola makanan dalam keluarga serta memiliki peranan besar dalam meningkatkan status gizi anggota (Noviyanti, et al, 2020) Ibu dengan latar belakang pendidikan tinggi akan sangat memperhatikan detail tumbuh kembang anaknya begitu pula sebaliknya, ibu dengan latar belakang pendidikan rendah akan cenderung abai dengan pola pertumbuhan dan perkembangan anaknya.

Berdasarkan tabel 2 ditemukan hasil bahwa, terdapat hubungan yang signifikan antara pengetahuan ibu dengan kejadian stunting dengan p-value 0,043. Hal ini sejalan dengan hasil penelitian yang di lakukan oleh (Ningtyas, et al, 2020) dapat diketahui bahwa proporsi balita yang 
mengalami stunting dengan ibu yang memiliki pengetahun gizi yang kurang sebesar $52,3 \%$, dan proporsi balita stunting dengan ibu yang memiliki pengetahuan gizi yang baik sebesar $16,9 \%$ dengan perolehan $\mathrm{p}$-value sebesar 0,000 ( $\mathrm{p} \leq 0,05)$.

Penelitian lainnya yang dilakukan oleh Angraini (2021) juga menghasilkan temuan yang sama yaitu berdasarkan hasil analisis bivariat menggunakan uji Chi-square menunjukkan $\mathrm{P}$ value sebesar 0,043 (p-value $<0,05$ ), artinya ada hubungan yang antara pengetahuan ibu dengan kejadian stunting.

Jika pengetahuan seseorang baik maka dapat disimpulkan bahwa ia akan menerapkan pola nutrisi dan dapat mengolah pangan dengan baik sehingga kecukupan gizi pada dirinya ataupun keluarganya akan terpenuhi (Pormes, 2014). Hal ini dapat menjadi gambaran bahwa tingkat pengetahuan ibu mengenai pemenuhan nutrisi pada masa keemasan anak sangatlah menunjang perkembangan serta pertumbuhan seorang anak (Wati, 2021).

Pengetahuan ibu yang kurang berdampak pada kurangnya perhatian terhadap asupan zat gizi yang diberikan ketika anak pada masa balita (Sutriyawan, 2020). Sebaliknya, ibu dengan tingkat pengetahuan yang baik akan menerapkan pengetetahuannya dalam mengasuh anaknya, khususnya memberikan makanan sesuai dengan zat gizi yang diperlukan balita, sehingga balita tidak mengalami kekurangan asupan makanan (Ni'mah, 2015).

\section{KESIMPULAN DAN SARAN}

Penyebab langsung (berat badan lahir dan tinggi badan ibu) dan penyebab tidak langsung (pendidikan, pengetahuan dan pola asuh) memiliki pengaruh yang signifikan dengan kejadian stunting pada anak balita.

Saran yang dapat diberikan dari hasil penelitian ini lebih menitik beratkan kepada pendidikan pra nikah kepada pasangan yang nantinya akan menjadi orang tua. Hal ini dikarenakan penyebab tidak langsung dari kejadian stunting dapat diminimalkan dengan edukasi yang tepat serta persiapan sebelum pasangan tersebut menikah dan memiliki keturunan. Selain itu tenaga kesehatan memiliki peran penting untuk mencegah bayi terlahir dengan berat badan rendah. Diperlukan juga kerjasama lintas sektoral bukan hanya bidang kesehatan namun bidang ekonomi, social, pembangunan dan pendidikan untuk menuntaskan akar permasalahan stunting.

\section{REFERENSI}

Aramico (2013) Hubungan Sosial Ekonomi, Pola Asuh, Pola Makan dengan Stunting pada Siswa Sekolah Dasar di Kecamatan Lut Tawar, Kabupaten Aceh Tengah.

Dinas Kesehatan DKI Jakarta (2017) Laporan Profil Kesehatan Provinsi DKI Jakarta. DKI Jakarta.

Fitri (2012) Berat Lahir Sebagai Faktor Dominan Terjadinya Stunting Pada Balita (12-59 Bulan) Di Sumatera (Analisis Data Riskesdas 2010). Universitas Indonesia.

Ibrahim, I. A. et al. (2019) 'Analisis determinan kejadian Growth failure (Stunting) pada anak balita usia 12-36 bulan di wilayah pegunungan desa Bontongan Kecamatan Baraka Kabupaten Enrekang', Al-Sihah: Public Health Science Journal, 11, pp. 50-64.

International Food Policy Research Institute (2014) Actions and Accountability to Accelerate the World's Progress on Nutrition, Washington, DC., Global Nutrition Report 2014.

Irawati, A., \& Salimar, S. (2014) 'Status Gizi Ibu Sebelum Hamil sebagai Prediksi Berat dan Panjang Bayi Lahir di Kecamatan Bogor Tengah, Kota Bogor: Studi Kohor Prospektif Tumbuh Kembang Anak Tahun 2012-2013', Nutrition and Food Research, 37(2), pp. 119-128.

Kemenkes RI (2018) 'Buletin Stunting', Kementerian Kesehatan RI, 301(5), pp. 1163-1178.

Ni'mah C, M. L. (2015) 'Hubungan Tingkat Pendidikan, Tingkat Pengetahuan dan Pola Asuh dengan Wasting dan Stunting pada Baita Keluarga Miskin.', J Media Gizi Indonesia, 10(1), pp. 8490. 
Ningtyas, Y.P, Udiyono, A., \& Kusariana, N. (2020) 'Pengetahuan Ibu Berhubungan Dengan Stunting Pada Balita Di Wilayah Kerja Puskesmas Karangayu Kota Semarang', Jurnal Kesehatan Masyarakat (Undip), 8(1).

Noviyanti, L. A., Rachmawati, D. A. and Sutejo, I. R. (2020) 'Analisis FaktorFaktor yang Memengaruhi Pola Pemberian Makan Balita di Puskesmas Kencong An Analysis of Feeding Pattern Factors in Infants at Kencong Public Health Center', 6(1), pp. 14-18.

Nurjanah, L. O. (2018) Faktor-Faktor Yang Berhubungan Dengan Kejadian Stunting Di Wilayah Kerja Upt Puskesmas Klecorejo Kabupaten Madiun Tahun 2018.STIKES Bakti Husada Mulia Madiun.

Pormes, W. E., Rompas, S., \& Ismanto, A. Y. (2014) 'Hubungan pengetahuan orang tua tentang gizi dengan stunting pada anak usia 4-5 tahun di TK Malaekat Pelindung Manado.', Jurnal Keperawatan, 2(2).

Proverawati A, C. I. (2010) BBLR: Berat Badan Lahir Rendah. Yogyakarta: Nuha Medika.

Ra, M. Y. And Anggraeni, L. (2021) 'Determinan Tidak Langsung Yang Mempengaruhi Kejadian Stunting Pada Balita Usia 24-59 Bulan Di Wilayah Kerja Puskesmas Kelurahan Cililitan Jakarta Timur', Prosiding Stikes Syedza Saintika, 1(1), pp. 577-585.

Rahmayana, Ibrahim, I. A. and Damayati, D. S. (2014) 'Hubungan Pola Asuh Ibu Dengan Kejadian Stunting Anak Usia 24-59 Bulan Di Posyandu Asoka II Wilayah Pesisir Kelurahan Ba- rombong Kecamatan Tamalate Kota Makassar Tahun 2014', VI(2), pp. 424-436.

Ramlah (2014) Ramlah. Available at: http://repositori.uin-alauddin.ac.id/6804/.
Sulistiyawati, A. (2019) 'Faktor-faktor yang Berhubungan dengan Kejadian Stunting pada Balita', Jurnal Ilmu Kebidanan, 5(1), pp. 21-30. doi: 10.33221/jikm.v9i02.505.

Sutriyawan A, N. C. (2020) 'Kejadian Stunting pada Balita di UPT Puskesmas Citarip Kota Bandung.', Jurnal Kesehatan Masyarakat Khatulistiwa, 7(2), pp. 79-88.

Torlesse H, Cronin A.A, Sebayang S.K, N. R. (2016) 'Determinants of stunting in indonesian children: evidence from a cross-sectional survey indicate a prominent role for the water, sanitation and hygiene sector in stunting reduction.', BMC Public Health.

Wati, S. K., Kusyani, A. and Fitriyah, E. T. (2021) 'Pengaruh Faktor Ibu ( Pengetahuan Ibu, Pemberian ASIEksklusif \& MP-ASI ) Terhadap Kejadian Stunting Pada Anak', 2(1).

Wells, J. C. K. (2013) 'Obesity as malnutrition: the dimensions beyond energy balance', European Journal of Clinical Nutrition, (January), pp. 507512. doi: 10.1038/ejen.2013.31.

World Health Organization (2016) Prevalence of anaemia in pregnant women. Jenewa.

Wulan Angraini, Mohammad Amin, Bintang Agustina Pratiwi, Henni Febriawati, R. Y. (2021) 'Pengetahuan Ibu, Akses Air Bersih Dan Diare Dengan Stunting Di Puskesmas Aturan Mumpo Bengkulu Tengah', Jurnal Kesehatan Masyarakat Khatulistiwa, 8(2), pp. 92-102.

Yabanc, N., K, İ. and Suzan, Ş. (2014) 'The effects of mother' $s$ nutritional knowledge on attitudes and behaviors of children about nutrition', 116, pp. 4477-4481. doi: 10.1016/j.sbspro.2014.01.970. 